\title{
Forest transitions in Chinese villages: Explaining community-level variation under the returning forest to farmland program
}

\author{
Zhiming Zhang ${ }^{\mathrm{a}}$, John Aloysius Zinda ${ }^{\mathrm{b}, *}$, Wenqing $\mathrm{Li}^{\mathrm{a}}$ \\ a Institute of Ecology and Geobotany, Yunnan University, Kunming 650091, People's Republic of China \\ b Department of Development Sociology, Cornell University, Ithaca, NY 14853, United States
}

\section{A R T I C L E I N F O}

Article history:

Received 14 March 2016

Received in revised form 10 February 2017

Accepted 10 February 2017

\section{Keywords:}

Forest transitions

Land use and land cover change

Payments for environmental services

Community

Rural development

China

\begin{abstract}
A B S T R A C T
China's Returning Farmland to Forest Program (RFFP) aimed to transform rural landscapes and livelihoods by compensating households for planting trees on retired farmland. The program has been attributed a key role in an apparent forest transition. Studies uncover great local variation in its impacts, but the mechanisms behind them have received little attention. We examine such heterogeneity in 12 communities in northwest Yunnan, assessing the hypothesis that the RFFP catalyzed a state-led forest transition by evaluating the contributions of RFFP implementation and other processes to land cover change. Our dataset combines socioeconomic data from household surveys, focus groups, and intensive interviews with remote sensing data for a linked, cross-scale analysis. Results show no significant relationship between RFFP implementation and community-level vegetation cover change. Between 2000 and 2010 , high-elevation communities had larger vegetation gains, while from 2010 to 2014, low-elevation communities had larger gains. Regression analyses and interview data show off-farm labor, tree crop planting, and changing energy sources influenced the rate of community-level vegetation change. This pattern, combining tree crop cultivation with labor outflows, may represent a distinct "policy plantation" pathway of forest gain. Meanwhile, new, high-elevation cash crops may be constraining forest expansion. This analysis suggests limited additionality for the RFFP in this region and highlights how heterogeneous, intersecting land use processes bring uneven forest transitions.
\end{abstract}

(c) 2017 Elsevier Ltd. All rights reserved.

\section{Introduction}

As the roles of forests in microclimate regulation, erosion containment, habitat provision, and climate change mitigation become increasingly evident, scholars and policymakers have focused attention on processes that promote gains in woody vegetation (Chazdon, 2008; Meyfroidt and Lambin, 2011). This concern motivates research on forest transitions, in which land change regime shifts from forest loss to stable or increasing forest cover (Mather, 1992; Mather and Needle, 1998). Initially conceived of as resulting from changes in prices and labor allocation that accompany industrialization and urbanization, forest transitions-and their absence-may follow from a variety of economic, political, and social processes (Meyfroidt and Lambin, 2011; Rudel et al., 2005). These processes play out differently across sociopolitical contexts and at differing scales (Lambin and Meyfroidt, 2010). Examin-

\footnotetext{
* Corresponding author.

E-mail addresses: zhiming_zhang76@hotmail.com(Z.Zhang),jaz65@cornell.edu (J.A. Zinda),253882057@qq.com (W. Li).
}

ing heterogeneity in changing land use and land cover patterns promises to help us better understand when and where forest transitions take place, as well as when particular social and environmental benefits are likely to accompany them.

This task has gained urgency amid a proliferation of policies aimed at controlling forest loss or promoting afforestation. Many of these policies take the form of programs payments for environmental services (PES), under which governments or other actors provide land users with incentives in exchange for undertaking land use practices that establish or conserve forests (Engel et al., 2008; Wunder, 2008). Many of these policies are intended to encourage forest transitions, but analysts debate their effectiveness (Alix-Garcia and Wolff, 2014; Daniels et al., 2010). Other policy instruments or concurrent processes, such as changes in commodity prices or market access, may obscure, offset, or intensify PES impacts (Lambin et al., 2014). As a result, rigorously evaluating forest restoration policies requires linking quantitative analyses with "process-based, qualitative understanding of causal pathways and indirect effects" (Lambin et al., 2014; p. 131).

China's Returning Farmland to Forest Program (RFFP; also translated as the Sloping Land Conversion Program and the Grain for 
Green Program) is of signal concern in these discussions. Commensurate with the program's aims to afforest 14.67 million ha of land-an area nearly the size of Nepal-and in the process lift tens of millions of marginal farmers out of poverty, the RFFP has garnered immense attention (Liu et al., 2008). Billed by some the world's largest PES program (Liu et al., 2008; Bennett, 2008; Yin et al., 2014), the RFFP has played a major role in transformations of land and livelihoods (He and Sikor, 2015; Lin and Yao, 2014; Zhen et al., 2014). But heterogeneous impacts raise questions about just what this role is (Gutiérrez Rodríguez et al., 2016). Examining this program within local contexts provides an opportunity to assess this policy's impacts alongside processes associated with other forest transition pathways. More broadly, understanding land cover change mechanisms under the RFFP is important for grasping China's diverse forest transitions and the promise and pitfalls of state-led PES programs worldwide.

The confluence of state policy and market-facilitated processes influencing land use has complicated efforts to understand the significance of the RFFP. Bearing hallmarks of both developmental and state-led pathways, China presents an ambiguous case of forest transition. In this study, we assess the hypothesis that the RFFP catalyzed a state-led forest transition in upland southwest China. Joining quantitative analyses of land cover to narrative accounts from semistructured interviews in twelve communities, we assess the relative contributions of RFFP and other contemporaneous processes to vegetation change.

\section{Parsing forest transitions}

\subsection{Forest transitions and incentive-based forestation}

A forest transition occurs when the pattern of land cover change over time in a defined space shifts from forest loss to stable forest cover or forest gain. In seminal works, (Mather 1992; Mather and Needle, 1998) compared national forest transitions to demographic transitions that have been observed to follow industrialization and urbanization. In this picture, changing prices and opportunities accompanying industrial modernization lead rural land users to abandon marginal cropland, intensify agriculture in high-quality farmland, seek urban employment, and plant trees to capture rising timber prices. These processes converge to slow and then reverse forest loss.

These observations spurred inquiries aimed at identifying differing "pathways" that forest transitions take and specifying under what conditions one or another pathway predominates. Rudel et al. (2005) identify alongside this "development path" a "forest scarcity path" in which governments respond to concerns about forest product shortages and natural disasters by implementing afforestation policies. Subsequent research has distinguished between a forest scarcity path, which may be driven by non-state actors concerned about forest product supply, and a "state-led" path, which may or may not be oriented toward forest scarcity but hinges on national policies pursuing forest expansion (Lambin and Meyfroidt, 2010; Meyfroidt and Lambin, 2011). In addition, (Meyfroidt and Lambin, 2008, 2011; Lambin and Meyfroidt, 2010) highlight the effects of globalization through policy, markets, and conservation ideology, as well as a smallholder intensification path in which farmers remain in an area but adopt intensive cultivation on productive lands while letting vegetation retake marginal fields.

Much of this work has followed (Mather, 1992; Mather and Needle, 1998) in exploring national-scale patterns (Mather, 2007; Meyfroidt and Lambin, 2011; Rudel et al., 2016, 2005). Yet as people have examined the implications of forest transition theory in studies with finer grains, questions of scale have become more prominent. First, researchers have questioned whether mecha- nisms proposed for national forest transitions work in the same ways at local (He et al., 2014; Klooster, 2003; Lambin et al., 2014; Xu et al., 2007), subnational (Meyfroidt and Lambin, 2008; Perz and Skole, 2003) or transnational scales (Lambin and Meyfroidt, 2011; Rudel et al., 2016). For example, the development pathway predicts national-scale vegetation increase resulting from shuffling within and across regions as landholders adjust land use to prices and productivity (Mather and Needle, 1998). It thus implies differing patterns at the national scale and within differently located subnational units, as areas with poor soils and rugged topography experience the greatest forest gains.

Second, different pathways may be likely to manifest at different scales. Smallholder intensification and forest scarcity pathways reflect responses to specific local conditions. In contrast, state-led pathways juxtapose national policies with local implementation patterns, while development and globalization pathways reflect patterned responses to broad but spatially heterogeneous exchange processes.

Third, asserting subnational patterns based on national-level data brings a risk of ecological fallacy (Rudel et al., 2016). Consider a hypothetical case in which smallholder intensification brought forest expansion in rugged peripheral areas, while rural-to-urban mobility surged in areas with easy access to cities but did not lead to afforestation in source areas. A carefully specified subnational model would be necessary to detect that smallholder intensification and not the aggregate demographic shift that generated the forest gains. Similarly, if national forest policies are poorly or unevenly implemented, their presence may not accurately account for land cover change patterns.

These questions of scale are closely related to the critique that forest transition theory can oversimplify complex and heterogeneous patterns. Multifarious local, national, and global processes mediate vegetation shifts. These include off-farm labor opportunities, land tenure and the extent of land scarcity, diffusion of techniques for crop or tree cultivation, access to markets, and conflict and warfare (Hecht, 2010; Perz, 2007). Processes associated with differing pathways may overlap, making it hard to tell which factors are decisive. As Lambin and Meyfroidt note, "when dealing with a particular case of land use transition, the elegant simplicity of a few clear-cut pathways gives way to rather messy interactions between elements of all the above pathways" (2010, p. 114). On the other hand, forest expansion may follow from processes that forest transition perspectives fail to account for. For example, Clement and Amezaga (2008), found that in the northern highlands of Vietnam forest gains occurred not due to but in spite of a state afforestation program, as deteriorating community institutions and changing markets altered what kinds of land use were feasible and desirable. Another study found that ethnic differences in migration and perennial crop cultivation brought varying local forest change patterns in the Ecuadorean Amazon (Rudel et al., 2002). Such studies highlight "the conjunctural nature of forest transitions and impl[y] that, if they occur, they will take place in an incremental and variable fashion, one small region at a time" (Rudel et al., 2002; p. 100).

These critiques have led people researching forest transitions to look inside the "black box" of national patterns to examine how the various processes associated with different forest transition pathways work, separately and in concert. In particular, the question of how state forest regeneration policies intersect with other processes elicits growing attention (Clement and Amezaga, 2008; He et al., 2014; Mather, 2007). Governments and other actors have a long history of attempting to spur forest transitions with an array of policy interventions (Lambin et al., 2014). These interventions have motley records of success. A recent meta-analysis shows that variation in policy, socio-political, and market environments differentiates the impacts of a given intervention type across locales, 
even as tenure security and effective enforcement facilitate positive forest outcomes (Agrawal et al., 2014). Amid the tangle of causal elements, parsing out what changes in land cover result from a policy intervention or other factors is a formidable challenge.

PES programs are bedeviled by just such questions. PES has become a principal intervention tool for forest restoration and maintenance (Alix-Garcia and Wolff, 2014). We adopt Muradian et al. definition of PES as "a transfer of resources between social actors, which aims to create incentives to align individual and/or collective land use decisions with the social interest in the management of natural resources" (2010, p. 1205). While some theoretical formulations posit voluntary, private transactions (e.g. Engel et al., 2008), state-led PES programs implemented by nation-states and localities have predominated among regional and national-scale initiatives (Alix-Garcia and Wolff, 2014).

Evaluations of PES programs center on efficiency, conditionality, additionality, and legitimacy. Efficiency is the extent to which intended outcomes are achieved relative to costs. Efficiency may depend on conditionality, the extent to which payments are made only if targeted behavior changes or environmental outcomes are delivered. Additionality is realized when behavior or land cover changes would not have occurred absent payments (Engel et al., 2008; Wunder, 2015, 2005). Practical challenges in achieving these goals highlight the importance of legitimacy: that participants treat the relationships and conditions of a PES arrangement as reasonable or tolerable. Legitimacy may depend on fairness, trust, cultural appropriateness, contribution to poverty alleviation, and political engagements that extend beyond the program intervention (Corbera et al., 2007; Kosoy et al., 2008; Muradian et al., 2010). Challenges to realizing these features highlight the complexities involved in designing and evaluating forest policy interventions. Where concurrent demographic shifts or economic development processes shape forest change, it raises questions about efficiency-the cost-effectiveness of payments-and additionality-how far the program makes a difference relative to other factors.

\subsection{The Returning Farmland to Forest Program}

Initiated in 1999 and expanded in 2002 to cover most of China's provinces, the RFFP provides farmers with compensation for planting trees on retired cropland and other uncultivated land. Policy documents require that participation be voluntary but also that land must be reforested based on erosion vulnerability criteria (State Council of the People's Republic of China, 2002). Farmers received payments based on the area of land retired, formally conditional on at least an $85 \%$ survival rate. Payments, initially in grain and later in cash, were promised annually for five or eight years depending on whether the trees planted were primarily considered of commercial or environmental value. In 2007 subsidy periods were extended, with smaller payments. ${ }^{1}$ These formal elements-payments conditional on provision of an environmental service undertaken on a voluntary basis-qualify the RFFP as a program of payments for environmental services (Muradian et al., 2010; Wunder, 2008). Analysts have suggested that, in conjunction with five other major forestry programs implemented at the same time and forestry initiatives implemented in the 1990s, the RFFP has facilitated a state-led forest transition in China (Robbins and Harrell, 2014; Rudel et al., 2005; Xu et al., 2007).

Yet the evidence on environmental and socioeconomic outcomes of the RFFP is a study in contrasts. Studies of land cover change at regional and provincial scales find gains in forest cover

\footnotetext{
1 For detailed discussions of the implementation of the RFFP, see Bennett et al. (2014) and Zinda et al. (2017).
}

in jurisdictions in which the RFFP was implemented (Chen et al., 2015; Li et al., 2013; Lü et al., 2012). At smaller scales, though, land cover change patterns vary sharply (Li et al., 2013; Van Den Hoek et al., 2014). Case studies identify mixed patterns of change, some finding successful forest establishment (He and Sikor, 2015) and others documenting failures due to poor species selection or inadequate participation of rural residents (Bennett, 2008; Trac et al., $2007,2013)$. The predominance of commercial plantations, which have been labeled "ecological forests" under a designation of dual environmental and commercial functions, raises further questions about the environmental benefits of RFFP forests (Frayer et al., 2014a; Zhai et al., 2013; Zinda et al., 2017).

Uneven local-scale environmental impacts are linked to heterogeneous socioeconomic patterns. Different studies have found positive, mixed, and negative impacts of RFFP on household income and off-farm labor participation (Kelly and Huo, 2013; Liang et al., 2012; Liu and Lan, 2015; Uchida et al., 2009, 2007; Xu et al., 2010; Yin et al., 2014), with substantial variation by locale (Liu et al., 2014; Song et al., 2014; Yao et al., 2010). Rates of compensation delivery and the extent to which residents perceive participation as voluntary vary sharply, even across townships in the same county (Bennett, 2008; Song et al., 2014; Zhou et al., 2007). Case study research highlights how locally specific livelihood opportunities (Bullock and King, 2011) and the ways local officials mediate implementation (He and Lang, 2015; Xu and Cao, 2002) differentiate the RFFP's social and land cover impacts.

This micro-level heterogeneity raises important questions about the interpretation of generalizations from large-scale analyses of the RFFP's impacts. While researchers regularly acknowledge variation, the usual analytical approach in large-scale studies has been to downplay the importance of heterogeneity, isolating main effects through statistical controls, rather than to take it as a valuable object of explanation in its own right. Yet for people who live in these places, the processes that bring successful implementation in one community and failure in an adjacent one are hugely consequential. Likewise, social variation in implementation likely combines with heterogeneous environmental conditions to shape the structure and spatial configuration of planted forests, attendant biological functions, and the environmental services that they provide (Lambin et al., 2014). Understanding the mechanisms that yield heterogeneous local outcomes requires attending to how policy, livelihoods, and broader economic processes interact.

These considerations also raise the question of the extent to which land cover change is due to RFFP implementation or to other causes. Studies that take watersheds, counties, and townships as units of analysis have found that jurisdictions in which RFFP is implemented tend to show greater forest cover increase than other jurisdictions (Deng et al., 2012; Li et al., 2013; Lü et al., 2012). Likewise, official assessments at RFFP monitoring sites, which likely face stronger pressures to demonstrate program success than other implementation sites, report strong performance (State Forestry Administration, 2014; SFA Economic Development Research Center and SFA Department of Development Planning and Assets Management, 2006). But the case literature cited above shows that at least some locales have diverged sharply from these outcomes. Evidence that non-participating households also retired substantial amounts of cropland (Frayer et al., 2014a; He and Sikor, 2015) raises questions about whether RFFP payments are primarily responsible for land cover change and to what extent other policies and shifts in agricultural and labor markets drive these changes.

\section{Materials and methods}

In light of recent calls to address uncertainties surrounding RFFP with comparative studies that integrate social and environmental 

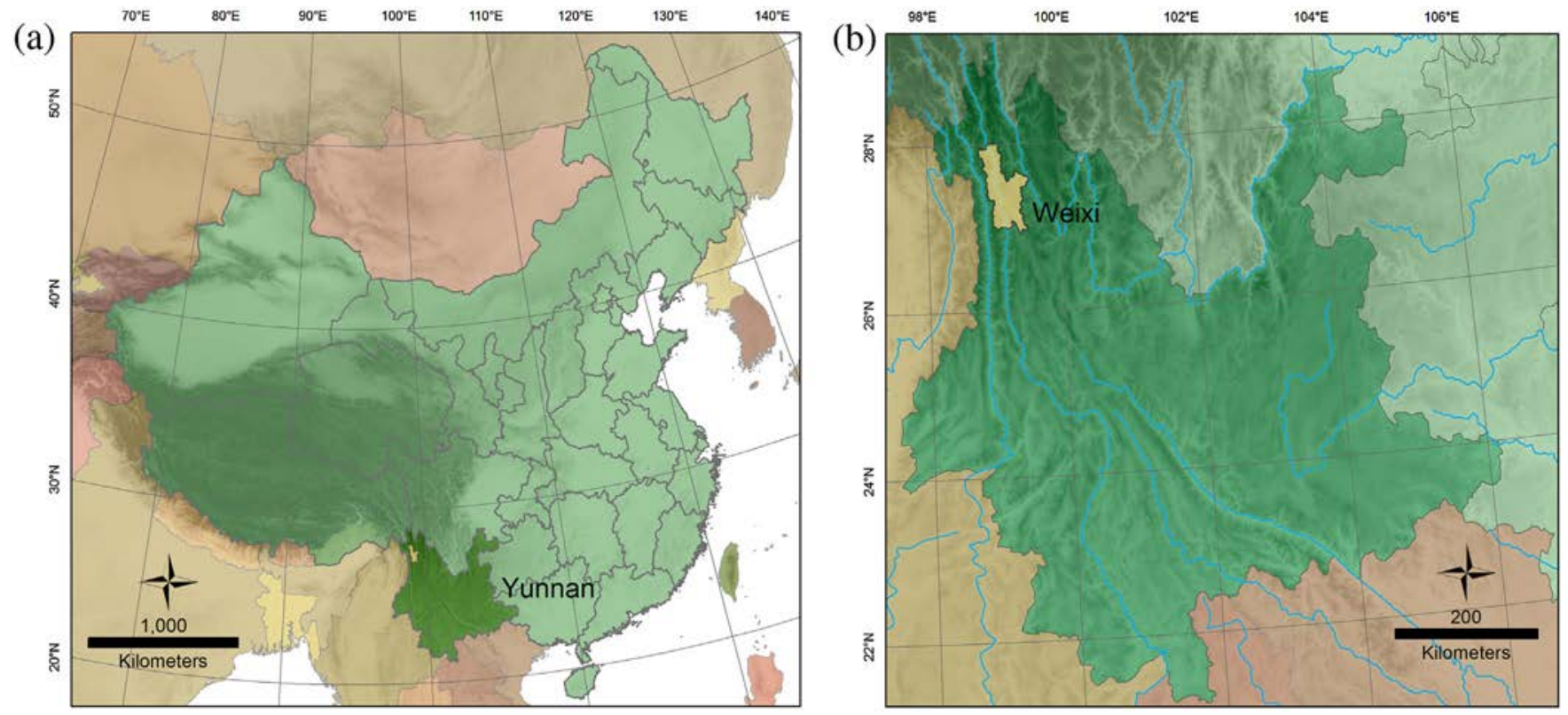

Fig. 1. Study location.

data (Song et al., 2014; Yin et al., 2014) and the questions about forest transitions discussed above, we present a multi-method comparison of land cover change and livelihood patterns in twelve communities. The concurrence of the RFFP with other processes influencing land use enables us to assess the relative impacts on vegetation change of the RFFP, indicative of a state-led pathway, and processes associated with development or smallholder intensification pathways. Our comparative design brings the attention to local context and contingency that is the strength of case studies while retaining some of the leverage of comparison that is the strength of large-n studies. The analysis addresses the following questions:

- Does RFFP participation account for community-level land cover change?

- What other factors and mechanisms might help explain variation in land cover change?

- How have the mechanisms influencing land cover change shifted over time?

\subsubsection{Study area}

We conducted field research in 2014 in Weixi Lisu Autonomous County in Yunnan Province, China (Fig. 1). Located in the province's mountainous northwestern area, Weixi's rugged terrain harbors substantial biological and cultural diversity. This region's biological importance and socioeconomic marginality make it significant with respect to both of the RFFP's central goals, forest establishment and poverty alleviation (Xu and Wilkes, 2004). The Lancang River (known downstream as the Mekong) flows through the county from north to south at elevations from 1380 to $1800 \mathrm{~m}$, between the Nu and Yunling mountain ranges, towering to $4880 \mathrm{~m}$. Winding folds of terrain hold varied biological communities with high endemism that have won the region recognition as the Mountains of Southwest China Biodiversity Hotspot (Conservation International, 2015). Most of the county's 150,000 residents belong to officially recognized minorities, including Lisu, Naxi, Bai, Tibetan, and Yi, living interspersed with a sizable Han Chinese population. Weixi's economy has historically been dependent on agriculture, forestry and mining, and it has regularly been listed a priority county for poverty alleviation. Logging contributed to rampant forest loss during the 1980s and 1990s, though a nationwide ban on commercial logging halted large-scale timber harvest by 2005 (Van Den Hoek et al., 2014).

These conditions made Weixi a priority site for RFFP implementation, and they reflect situations common across RFFP sites in western China. According to county forestry bureau personnel, 7500 ha were afforested under the program, equivalent to about one-quarter of the county's cropland at the time. Local government agencies claim that the RFFP is responsible for large forest cover increases (Yang Hongcheng, 2013). However, a recent study of forest policy impacts found net forest loss between 1999 and 2009 in all nine townships of Weixi County, though a much smaller rate of loss than in the preceding decade, and with substantial variation across townships (Van Den Hoek et al., 2014). These uncertainties give added reason to examine mechanisms of variable land cover change here.

\subsection{Interview and survey data}

We worked with officials in local forestry agencies to identify administrative villages and communities within them that had and had not implemented RFFP. Communities were selected on the basis of RFFP implementation, half with the program and half without. Within each RFFP-based subsample, we sampled along an elevation gradient, including communities at riverside, separated from the river by one community, and separated from the river by two or more communities. This gradient reflects both travel distance from major settlements and agroecological conditions associated with elevation. To minimize confounding biophysical influences, we sampled communities on the west bank of the river with predominantly east or southeast aspect. Restricting aspect lessens the likelihood that the effects of differing exposure to sunlight and precipitation on forest growth will confound analyses. ${ }^{2}$ The resulting sample included twelve communities located in two

\footnotetext{
2 We acknowledge that this approach risks introducing bias into our sample, as aspect differences could influence patterns of forest use and regrowth in communities outside the sampled population. Therefore, strictly speaking, our results are only generalizable to communities on eastward-facing slopes.
} 
Table 1

Satellite image data sources.

\begin{tabular}{lll}
\hline Sensor & Date & $\begin{array}{l}\text { Spatial resolution } \\
\text { of multi-spectral } \\
\text { band, m }\end{array}$ \\
\hline Landsat TM (ETM+) & $12 / 25 / 2000$ & 30 \\
Advanced Land Observation Satellite (ALOS) & $1 / 4 / 2010$ & 10 \\
Gaofen-1 & $11 / 8 / 2014$ & 8 \\
\hline
\end{tabular}

adjacent townships, including four at riverside; four at middling elevation, and four at high elevation. Five had implemented RFFP. This sample reflects the logic of maximum variation sampling, spanning the range of variation in a population to heighten the likelihood that a limited sample reflects the full variety present (Miles and Huberman, 1994).

We gathered socioeconomic data through a household survey, intensive interviews with officials and selected households, and focus group discussions. A household questionnaire was pretested during preliminary site visits in January and June 2014. In July and August of 2014, the authors and 11 trained enumerators visited each community. We worked with community officials to locate and interview an adult member of every household present. The questionnaire focused on household livelihood strategies, covering household demographics; labor allocation, land use, and income in crop cultivation, livestock husbandry, forest use, and off-farm work; RFFP participation; and community development. Interviews were conducted in Mandarin Chinese, with one-third facilitated by a resident speaking a local dialect, and took between $30 \mathrm{~min}$ and one hour. We obtained 421 valid questionnaires.

Within each community we selected six households for intensive interviews. Based on questionnaire responses, in each community two households each were randomly selected from high, middling, and low income terciles. During a follow-up visit in autumn 2014, we conducted semi-structured interviews with each of these households, covering household land use and labor allocation decisions as well as community history and institutions. These interviews totaled 71 . We also conducted 24 semi-structured interviews with community, administrative village, township, and county officials charged with community administration and forest management. These interviews discussed the individual's duties and experiences as an official and histories of policy implementation and community affairs.

In each community we conducted a focus group discussion covering the community's history of livelihood change, forest use, forest tenure change, and community affairs. Each focus group included three men and three women aged between 20 and 65 . Focus group discussions were conducted in Mandarin and lasted between 45 and $90 \mathrm{~min}$. With participants' informed consent, discussions were recorded and later transcribed.

\subsection{Remote sensing data}

Our remote sensing data are derived from three images acquired in 2000, 2010, and 2014 by three different sensors (ETM+, ALOS and Gaofen-1) with varying spatial resolutions (Table 1). These three time points represent one immediately preceding RFFP implementation, one recent capture, and one in between. Data availability limitations necessitated choosing 2010 rather than a midpoint between 2000 and 2014. However, because 2010 coincides with the onset of recent large-scale walnut plantation and expansion of other cash crops, using this point facilitates examining these processes.

Before landscape changes could be analyzed, the three land cover maps were generalized to improve the integration of data for change detection analysis, using the $30 \mathrm{~m}$ resolution of the 2000
Table 2

Land cover classes.

\begin{tabular}{ll}
\hline Class 1 & Class 2 \\
\hline Forest & Fir and spruce forest \\
Forest & Pine forest \\
Forest & Mixed forest \\
Shrub & Low density forest and tall shrubs \\
Shrub & Dwarf shrub and meadow \\
Agricultural land & Agricultural land \\
Snow & Snow \\
Water & Water \\
Cast shadow & Cast shadow \\
\hline
\end{tabular}

map. This procedure increases percentage agreement between source and target map following spatial aggregation (Petit and Lambin, 2001).

We performed a classification of satellite image data to prepare three land cover maps, using a feed-forward back-propagation algorithm artificial neural network (Atkinson and Tatnall, 1997; Benediktsson et al., 1990; Mas and Flores, 2008). Nine land cover classes were selected based on (i) adequacy in capturing major land cover types, (ii) feasibility of identification using Landsat, ALOS, and Gaofen-1 image data, and (iii) relevance to vegetation change. The image processing protocol used to prepare the vegetation maps has been described by Zhang et al. (2014). To address the effects of RFFP on differences in land cover change patterns between communities with and without RFFP, the nine land cover classes were grouped into six categories: forest, shrub, agricultural land, and three non-vegetation classes (snow, water, shadow) (Table 2). The non-vegetation classes were excluded from further analysis.

We created a polygon layer representing community boundaries, digitized from paper maps and manually georectified with reference to the 2010 ALOS image in ArcGIS 10.3.1. As focus group and interview respondents in high-up communities reported that they used state forests beyond community boundaries for fuel and other forest products, we extended those boundaries to proximate ridges. We used data from a $25 \mathrm{~m}$ resolution digital elevation model produced by the China State Bureau of Surveying and Mapping (Wang, 2006) in a Topographic Position Index extension for ArcGIS (Jenness, 2006). Where communities abutted land not belonging to any community, boundaries were extended upward in elevation to the nearest ridge or community boundary. We used this layer to clip land cover rasters for each community, which served as units of comparison in analyses.

\subsection{Analysis}

We imported focus group transcripts and notes from qualitative interviews into nVivo 10 , coding the texts for themes emerging from respondents' accounts and our research questions, and comparing the presence, absence, and sequencing of different themes across communities. Questionnaire data were entered into a spreadsheet and, after checking and cleaning, imported into StataSE 14. We constructed community-level measures of crop cultivation, livestock husbandry, RFFP participation, and off-farm labor allocation. We incorporated land cover change measures from the remote sensing analysis into the dataset, constructing variables representing annualized rates of change in proportion of agricultural, shrub, forest, and combined forest and shrub cover within each community, as well as fragmentation metrics for each of these land cover categories. Because the primary concern of this study is the rate of conversion from agricultural land to non-row-crop vegetation, we summed the categories "Forest" and "Shrub" into a single category "Combined Vegetation." Variables used in models presented here are described in Table 3. We tested relationships between land cover measures and biophysical, policy, and behav- 
Table 3

Variable descriptions. Means and standard deviations are for community values.

\begin{tabular}{|c|c|c|c|}
\hline Variable & Description & Mean & SD \\
\hline Change in Forest Cover, 2000-2010 & Change in proportion forest cover of community area not identified as & 0.00556 & 0.00736 \\
\hline Change in Forest Cover, 2010-2014 & shadow, water, or other. & 0.02154 & 0.01808 \\
\hline Change in Shrub Cover, 2000-2010 & Change in proportion shrub cover of community area not identified as & 0.00231 & 0.00902 \\
\hline Change in Shrub Cover, 2010-2014 & shadow, water, or other. & -0.01036 & 0.02150 \\
\hline Change in Vegetation Cover, 2000-2010 & Change in proportion combined forest and shrub cover of community area & 0.00787 & 0.00611 \\
\hline Change in Vegetation Cover, 2010-2014 & not identified as shadow, water, or other. & 0.01118 & 0.01180 \\
\hline Proportion Vegetation Cover, 2000 & Proportion of community area not identified as shadow, water, or other & 0.54307 & 0.21809 \\
\hline Proportion Vegetation Cover, 2010 & covered by shrub or forest vegetation. & 0.62176 & 0.20893 \\
\hline Mean Elevation & Mean elevation of all pixels within adjusted community boundaries. & 2108 & 268.48 \\
\hline Elevation Category & $\begin{array}{l}\text { Categorization by proximity to riverside: } 0=\text { riverside, } 1=\text { separated from } \\
\text { river by one community, } 2=\text { separated from river by } 2 \text { or more } \\
\text { communities. }\end{array}$ & 1 & 0.85280 \\
\hline Household Density & $\begin{array}{l}\text { Number of households in } 2014 \text { divided by community area in square } \\
\text { kilometers }\end{array}$ & 27.99 & 10.23 \\
\hline RFFP Implementation & Binary, 1 = implemented RFFP, 0 = did not implement RFFP & 0.41667 & 0.51493 \\
\hline Off-Farm Proportion & Proportion of surveyed households reporting off-farm labor in 2013. & 0.48704 & 0.16897 \\
\hline Cash Crop Sale & Proportion of surveyed households reporting selling cash crops in 2013. & 0.21147 & 0.32553 \\
\hline Solar Water Heaters & $\begin{array}{l}\text { Proportion of surveyed households reporting having installed a solar } \\
\text { water heater in } 2013 .\end{array}$ & 0.22902 & 0.32665 \\
\hline Walnut Area & $\begin{array}{l}\text { Area of walnut tree plantation in community: sum of household responses } \\
\text { adjusted for nonresponse rate. }\end{array}$ & 5.18 & 1.80 \\
\hline
\end{tabular}

ioral predictors using bivariate comparisons, ANOVA, and ordinary least squares regression. Tests for normality, skew, kurtosis, heteroskedasticity, and multicollinearity were all within acceptable ranges. In an iterative process, we tested models based on hypotheses that emerged from qualitative analyses and revisited qualitative data following quantitative analysis to evaluate and contextualize model results. In presentations below, all names of places and persons are pseudonyms.

\section{Results}

\subsection{RFFP and community-level land cover change}

All study communities showed net vegetation increase between 2000 and 2014, and all but one showed net gain in forest cover. Rates of change in agricultural, shrub, forest, and combined vegetation covers varied substantially across communities and time periods (Fig. 2). The correlation between change in combined vegetation in 2000-2010 and 2010-2014 was negative but not statistically significant.

We conducted Student's $t$-tests to examine whether land cover change metrics varied based on whether a community had implemented the RFFP (Table 4). We tested differences over the entire period as well as for the periods 2000-2010 and 2010-2014 to assess the possibilities that RFFP might have had an accentuated effect immediately following implementation and that its effects might be delayed due to the time required for canopy formation. For no cover, during neither period nor the entire duration between 2000 and 2014, did RFFP implementation show a significant effect.

\subsection{Community experiences and mechanisms of variation}

If RFFP implementation does not account for variation in vegetation change, what does? To generate hypotheses from residents' accounts, we combined qualitative data from focus groups and interviews with quantitative data from survey results to make a case study of each community. The following paragraphs summarize observations from three communities, highlighting common and diverging patterns that we examine quantitatively below.

We start Huoba, which implemented RFFP and showed the second-highest rate of vegetation gain for 2000-2010 and highest rate for 2000-2014. A middle-elevation community, Huoba's residents have moved from a mixed cropping pattern including wheat,
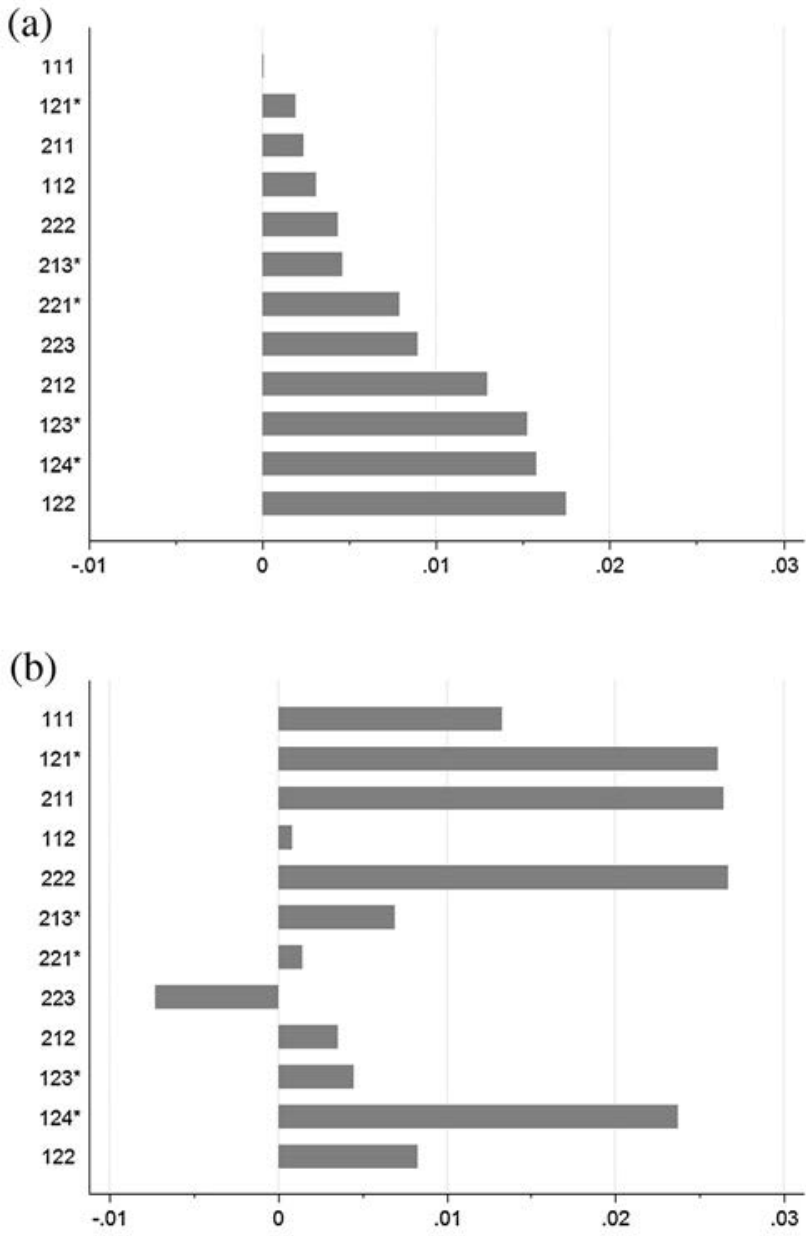

Fig. 2. Annual change in proportion cover in forest and shrubs for each study community. (a) 2000-2010. (b) 2010-2014. * indicates communities that implemented RFFP.

sorghum, buckwheat, and maize, to almost exclusive cultivation of maize for livestock feed, with a large proportion of maize fields hosting walnut saplings. Half of its 16 households undertook offfarm labor in 2013. Every household took part in RFFP, with each 
Table 4

RFFP implementation and land cover change, $t$-tests. (a) 2000-2010; (b) 2010-2014; (c) 2000-2014.

(a)

\begin{tabular}{|c|c|c|c|c|c|c|}
\hline & \multicolumn{2}{|l|}{ Non-RFFP } & \multicolumn{2}{|l|}{ RFFP } & \multirow[b]{2}{*}{$\mathrm{t}$} & \multirow[b]{2}{*}{$\mathrm{p}$} \\
\hline & Mean & Standard Deviation & Mean & Standard Deviation & & \\
\hline Agricultural & -0.00702 & 0.00634 & -0.00906 & 0.00627 & 0.553 & 0.593 \\
\hline Shrub & 0.00279 & 0.00914 & 0.00163 & 0.00988 & 0.210 & 0.838 \\
\hline Forest & 0.00423 & 0.00785 & 0.00743 & 0.00700 & -0.727 & 0.484 \\
\hline Combined Vegetation & 0.00702 & 0.00634 & 0.00906 & 0.00627 & -0.553 & 0.593 \\
\hline
\end{tabular}

(b)

\begin{tabular}{|c|c|c|c|c|c|c|}
\hline & \multicolumn{2}{|l|}{ Non-RFFP } & \multicolumn{2}{|l|}{ RFFP } & \multirow[b]{2}{*}{$\mathrm{t}$} & \multirow[b]{2}{*}{$\mathrm{p}$} \\
\hline & Mean & Standard Deviation & Mean & Standard Deviation & & \\
\hline Agricultural & -0.01024 & 0.01283 & -0.01251 & 0.01150 & 0.316 & 0.759 \\
\hline Shrub & -0.01161 & 0.01790 & -0.00861 & 0.02799 & -0.227 & 0.825 \\
\hline Forest & 0.02184 & 0.01157 & 0.02113 & 0.02642 & 0.065 & 0.950 \\
\hline Combined Vegetation & 0.01024 & 0.01283 & 0.01251 & 0.01150 & -0.316 & 0.759 \\
\hline
\end{tabular}

(c)

\begin{tabular}{|c|c|c|c|c|c|c|}
\hline & \multicolumn{2}{|l|}{ Non-RFFP } & \multicolumn{2}{|l|}{ RFFP } & \multirow[b]{2}{*}{$\mathrm{t}$} & \multirow[b]{2}{*}{$\mathrm{p}$} \\
\hline & Mean & Standard Deviation & Mean & Standard Deviation & & \\
\hline Agricultural & -0.00794 & 0.00452 & -0.01005 & 0.00523 & 0.748 & 0.472 \\
\hline Shrub & -0.00132 & 0.00684 & -0.00129 & 0.01336 & -0.005 & 0.996 \\
\hline Forest & 0.00926 & 0.00409 & 0.01134 & 0.01048 & -0.484 & 0.639 \\
\hline Combined Vegetation & 0.00794 & 0.00452 & 0.01005 & 0.00523 & -0.748 & 0.472 \\
\hline
\end{tabular}

household allowed to choose the amount and location of retirement. Participation was broad, but constrained by a sense of risk. As one resident recalls,

Some retired 10 or $15 \mathrm{mu}$, but I didn't dare. They said that if you didn't tend them well, you would be fined. But no one actually got fined, even when trees didn't do well. They retired more, planted more, and if it didn't turn out well, the government still gave money. Later I thought I'd retired too little.

While worries about subsidy nondelivery did not play out, fears about tree performance did. Another resident says,

After the first year, the walnuts the government gave out were half dead. Some were already withered, only useful as firewood! We had to find saplings in the forest to replant. We replanted for several years. Early on RFFP didn't allow planting crops, but later we could interplant corn and sorghum and green fertilizer. The walnut trees have fruited, but not enough to sell.

In every participating community, initial RFFP plantings floundered, requiring labor-intensive replanting until 2007 when the ban on intercropping was lifted. When residents began planting maize and green fertilizer among seedlings, walnut trees flourished, though at the time of research few were yet bearing fruit. Huoba's RFFP plots vary widely, from grazed hillsides with a scant walnut here and there to cornfields hosting juvenile trees to pine thickets that have overtaken walnut saplings.

Neighbors Garuanba and Muban show contrasting patterns across elevation. Garuanba is a large middle-elevation community with access to high-elevation land. Muban sits directly below along the riverside. Garuanba residents participated in RFFP, but in a very different way from Huoba. The township housing Garuanba required retirement in contiguous tracts, and households were only included if they had land in these areas. As in Huoba, residents planted walnuts interspersed with Sichuan pepper and Prinsepia utilis, a bush whose berries yield marketable oil. Tou, who served as forest manager for the village, mediated several changes in RFFP implementation. First, he negotiated with higher-level officials to add a second tract to include more households than initially targeted. Second, he directed the plantation of an area of collective land with Chinese white pine (Pinus armandii), increasing subsidies without further household cropland retirement. Third, in the face of failing walnut plantations, he obtained permission to sow pine seed in household plots. These actions helped put Garuanba's vegetation gain for 2000-2010 in the top half of studied communities. Subsequently, negative experiences with walnuts led to lukewarm reception of later walnut programs. Meanwhile, costus root (Saussurea costus), a medicinal plant related to ginger, and runner beans (Phaseolus coccineus), have become profitable cash crops. Residents have cleared upslope fern and shrub thickets to plant them. These activities have constrained non-agricultural vegetation spread, and Garuanba's vegetation gains in 2010-2014 were among the lowest in the study.

Residents of Muban planted uphill farmland with walnut and chestnut in anticipation that they too might cash in on RFFP. But Muban was not included in the program. Nonetheless, residents did not reclaim the plots, and the surrounding Yunnan pine (Pinus yunnanensis) forest gradually engulfed them. Labor had become scarce as off-farm work took off, with 4 in 5 households reporting offfarm labor in 2013. 9 in 10 households took part in later walnut planting, compared to less than half in Garuanba. As abandoned farmland revegetated and walnut plantations took hold, from 2010 to 2014 Muban showed the highest rate of vegetation gain of any study site.

\subsection{Bringing in biophysical and behavioral factors}

These cases highlight complications in RFFP implementation as well as the effects of other contemporaneous processes. The lack of a clear effect of RFFP across communities might be due to other covarying influences obscuring or countervailing its impacts. Biophysical or behavioral factors associated with elevation and population density might affect RFFP implementation as well as forest use more generally. When communities are grouped by elevation category, for the period 2000-2014, no differences in vegetation change are evident. However, when the two shorter periods are considered separately, two complementary patterns emerge (Fig. 3). Between 2000 and 2010, communities in middling and high elevation categories showed sharp increases in vegetation cover, while riverside communities showed smaller rates of gain. In contrast, between 2010 and 2014, high and middling com- 


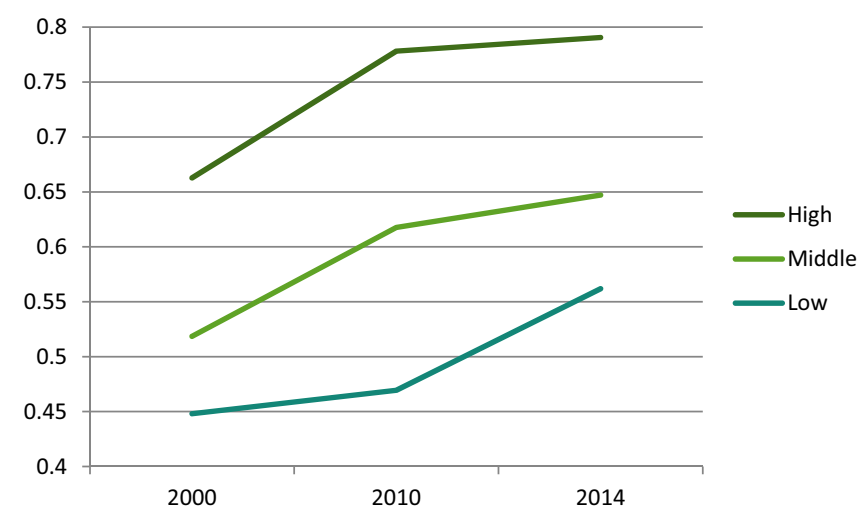

Fig. 3. Proportion non-agricultural vegetation cover by elevation category, 2000-2014.

\section{Table 5}

Vegetation change by elevation category: (a) ANOVA, 2000-2010 and 2010-2014; (b) table of means by elevation. Superscripts a and b indicate significant difference, $\mathrm{p}<0.1$.

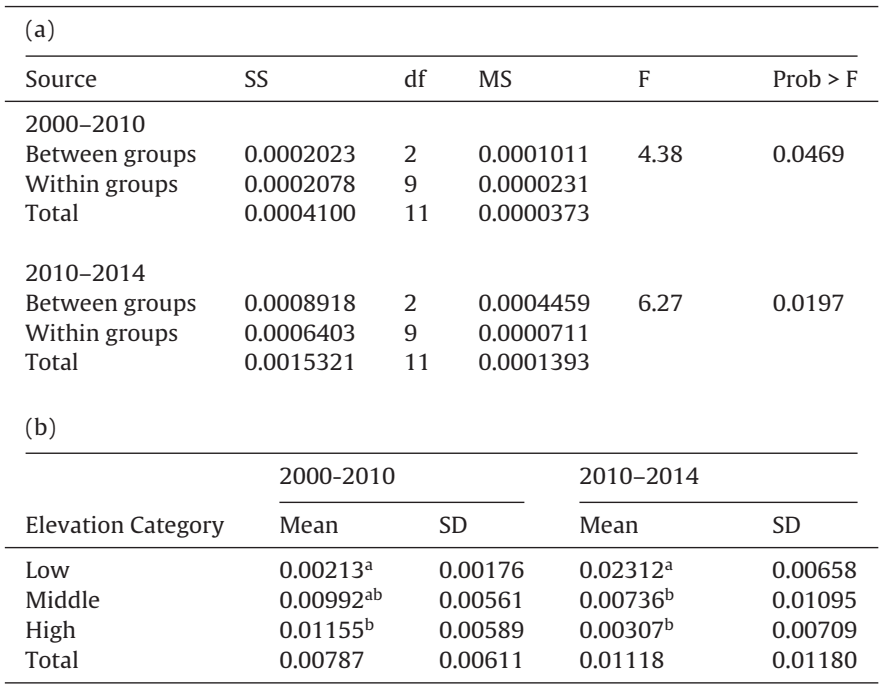

munities showed slower vegetation change, while vegetation gain accelerated in riverside communities. Tested using ANOVA and post-hoc tests (Tukey's HSD, Bonferroni, Scheffé, Sidák), differences between low and high communities were marginally significant in 2000-2010 ( $p<0.1$ ), and significant but in the opposite direction in 2010-2014 ( $\mathrm{p}<0.05)$, while change rates in middle elevation communities were between the other two in both periods (Table 5).

Livelihood activity patterns influence land change together with biophysical conditions. Field observations revealed varying patterns of agricultural land use as well as other activities. These patterns are evident in the community data, with off-farm labor, adoption of cash crops, walnut cultivation, livestock specialization, and installation of solar water heaters concentrated in different communities. Each of these activities could plausibly influence vegetation through clear mechanisms. Off-farm labor is likely to reduce forest use by diminishing available labor and demand for forest products (Qin, 2010). The prevalent cash crops, runner beans and costus root, occupy high-elevation land, possibly constraining vegetation gain. Walnut cultivation, on the other hand, could increase canopy cover. Livestock husbandry demands fodder as well as firewood for heating feed, likely impacting vegetation negatively (Willson, 2006). Finally, solar water heaters have substantially cut firewood demand in several communities. Surprisingly, given the RFFP's goals of agricultural intensification and off-farm labor shift,
Table 6

OLS regression analyses: annual change in proportion combined vegetation cover regressed on human-ecological variables, activity indicators, and RFFP implementation status, (a) 2000-2010 and (b) 2010-2014. $\mathrm{N}=12$. P-values in parentheses. * $\mathrm{p}<0.05,{ }^{* *} \mathrm{p}<0.01,{ }^{* * *} \mathrm{p}<0.001$.

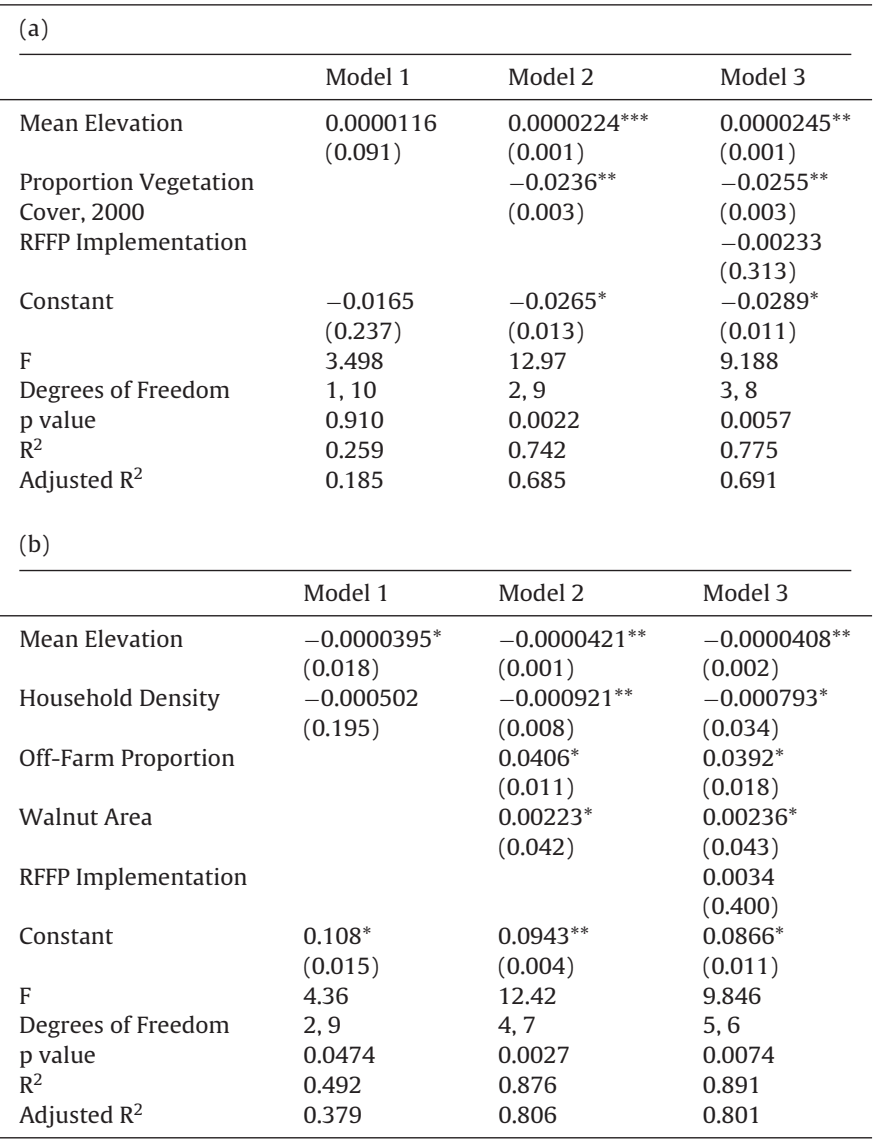

none of these activities shows a significant correlation with RFFP implementation at the community or household level.

We tested several ordinary least squares (OLS) regression models predicting vegetation change in each period. For both periods, we assessed a suite of human-ecological predictors including elevation measures, household population density, and proportion vegetation cover at the beginning of the period. ${ }^{3}$ We label these variables human-ecological because they constitute both environmental attributes and associated patterns of human activity. Elevation, for example, represents not only biophysical conditions influencing vegetation growth but also travel time and conditions affecting crop cultivation. For 2010-2014, we successively tested models including human activity indicators in combination with significant human-ecological predictors and with one another. We lack robust data on these variables for the earlier period, as information could only be accessed through recall. Finally, we tested models including RFFP implementation status alongside other significant predictors.

For 2000-2010, the strongest predictors were mean elevation, with a positive and highly significant effect, and proportion vegetation cover in 2000, with a negative and significant effect (Table 6). The effect of elevation translates to a difference across the first and

\footnotetext{
${ }^{3}$ For each set of regressions, we tested separate models using measures of household population density and proportion vegetation cover at the beginning of the period. These variables are positively correlated and could not be included in the same model due to multicollinearity. For each model presented, we use the measure that proved the strongest predictor across a range of stepwise regression procedures.
} 
third quartiles of $0.9 \%$ per year vegetation change-approximately 1.5 standard deviations. Adding RFFP implementation does not improve model fit.

For 2010-2014, mean elevation remains a strong predictor, but its effect is negative. With other components held constant, moving from the first quartile to the third quartile in elevation corresponds with a decrease in annual vegetation change by $1.85 \%$, summing to $7.4 \%$ over 4 years (Fig. 4 ). The effect of household density is negative and significant, while the effects of off-farm labor prevalence and walnut plantation area are positive and significant (Table 6). Moving from the bottom quartile to the top quartile in household density corresponds to a decrease in vegetation gain of $0.4 \%$ of a community's area per year. Again, the effect of RFFP implementation is small and insignificant.

These analyses suggest important roles of human-ecological variables and community livelihood patterns. The small size of the sample limits the number of predictors and prevents addressing interactive effects. Yet qualitative observations indicate that other activities, highly correlated with elevation and household density, also have important impacts. For example, in several highelevation communities, cash crops have revolutionized livelihoods since their adoption around 2010. Residents reported clearing trees and bracken to plant these crops. The only community with a net loss of combined vegetation in 2010-2014, 223, had the secondhighest rate of cash crop sale. Meanwhile, in several riverside communities, the installation of solar water heaters has brought sharp reductions in firewood use. Measures of both activities have strong bivariate correlations with 2010-2014 vegetation change, negative for cash crops and positive for solar water heaters. We conducted nested regression models for each, starting with a univariate model and adding human-ecological predictors. In each case, with the inclusion of mean elevation in the model, the effect size halved and lost significance as correlation with elevation obscured the negative effect of cash crop adoption on vegetation change in highup communities and the positive effect of solar water heaters in riverside communities. Models using measures of livestock holdings found no significant effects (Supplementary material, Tables S1-S3).

\section{Discussion}

\subsection{A dynamic forest transition}

Our data show an overall trend of forest expansion that could be construed to indicate successful forest expansion policy. All communities showed net gain in vegetation cover, and all but one net gain in forest cover. Whatever mix of policy, market, and other causes is responsible, over the study area the Chinese government's goal of increasing forest cover appears to be advancing, marking a shift from prior forest loss (Van Den Hoek et al., 2014). However, across study sites, RFFP implementation does not bring significantly greater vegetation gain. Instead, a combination of linked biophysical and behavioral patterns identified in residents' accounts explains variation. If the elevation effect were consistent over time, it would be defensible to attribute trends mainly to biophysical conditions. The switch in direction across time periods supports the claim that the effect reflects behavioral factors associated with elevation. Because these patterns are tightly interlinked, with agricultural activities and market access structured by local socioeconomic and biophysical conditions, they are not easily amenable to analysis using conventional modeling approaches.

We document a temporal shift in patterns and causes of land cover change, indicating change in the drivers of land use and land cover change over time. From 2000-2010, high-elevation communities and communities with smaller initial non-agricultural vegetation cover experienced the largest vegetation gains. During this period marginal cropland was key. In high-elevation communities, residents had practiced expansive, often swidden-based, cultivation of hardy but low-productivity crops such as buckwheat, barley, and oats on steep, dispersed plots. During this decade, as the returns to marginal agriculture fell and government agencies discouraged swidden, residents took up intensive maize cultivation closer to their settlements, which was more productive and required less labor. In some cases this shift was accompanied by RFFP subsidy and plantation, and in others not, but uneven survival of planted trees constrained the land cover impact of RFFP relative to abandonment due to other causes. This pattern suggests forest expansion driven by smallholder intensification.

By 2010, high-elevation communities had retired substantial farmland already. A resurfaced highway along the Lancang River and branch roads to communities connected residents to markets for labor and agricultural products. The walnut-planting program begun in 2008 initially targeted riverside communities, whose fertile soil and gentler slopes favor orchard establishment. At the same time, residents of high-elevation communities found new opportunities to market beans and medicinal crops. The result was a shift toward faster vegetation gain at low elevations. With its involvement of labor outflows and market connections, this pattern bears a resemblance to the peripheral component of a development pathway, but the role of policy programs bringing forest expansion at lower elevations diverges from that path.

\subsection{Rethinking the RFFP and PES}

These findings raise the possibility that the relationship between RFFP implementation and land cover change is less straightforward than has been suggested. Some studies have assumed that if forest gain is observed in places where RFFP was implemented, it is due to RFFP, or that if land was enrolled in RFFP then forest gain would take place. The evidence we present suggests that spatially and temporally situated activity patterns better account for vegetation gain in Weixi. Associations between RFFP implementation and vegetation gain in a county or township may be spurious due to relationships between RFFP and other land use processes. In that case, prevalent narratives may give excessive credit for forest gains to the RFFP and not enough to the farmers who reorient their livelihoods due to various policy, market, and aspirational reasons.

This observation does not imply that the RFFP did not bring additional vegetation gains anywhere. Insignificant effects at a local scale do not rule out observable impacts at other scales or locations. Indeed, the diverse findings of place-sensitive studies lead us to expect that other locales, with different economic conditions and policy implementation patterns, will show varying impacts and mechanisms. Research on land cover change processes might be improved by introducing models that differentiate across regions and address interactions among geography, topography, and livelihood activities. Recent studies by Yin et al. (2014) and Bennett et al. (2014) make promising steps in this direction.

One possible response to these findings is to claim that, at least in the context of northwest Yunnan, the RFFP did not achieve its goals and was a waste of money. We think this argument is unwarranted. First, while RFFP compensation did not keep pace with rising costs and earnings, RFFP compensation made a difference in the lives of impoverished people, especially at its onset. Otherwise, people would not have shown the motivation to participate that our respondents expressed. RFFP subsidies may have helped participants weather livelihood transitions (Uchida et al., 2009). Second, the RFFP may have played a role in learning processes that facilitated more successful walnut cultivation later. Where walnut planting did succeed, the demonstration effect may have helped 

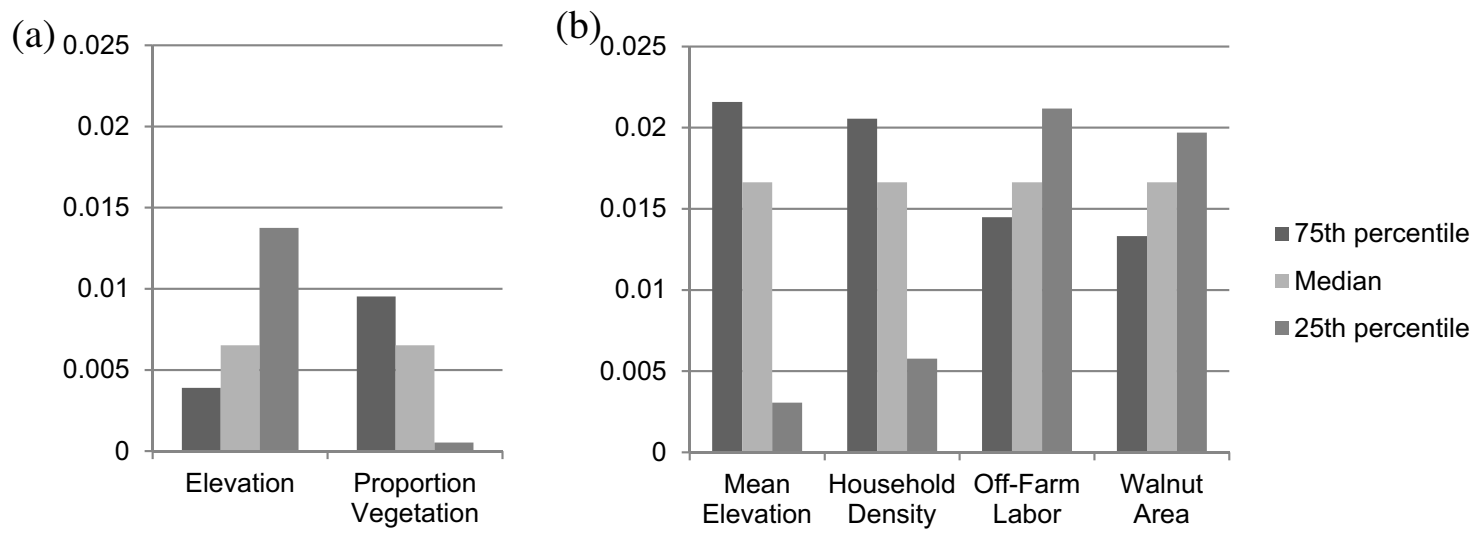

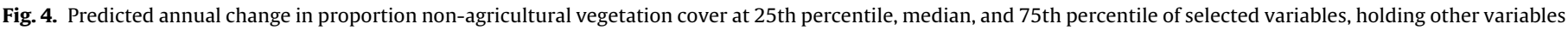
at their medians: (a) 2000-2010; (b) 2010-2014.

persuade farmers to plant trees subsequently (Frayer et al., 2014b). Success and failure may have brought lessons that helped officials implement and provide support for later tree planting.

Several considerations regarding PES follow. Rates of vegetation change in communities that implemented RFFP are indistinguishable from those in communities that did not, showing limited additionality of the RFFP in this region. Concurrent changes in markets for labor and agricultural products drove farmland abandonment, and it is plausible that these forces would have brought vegetation expansion in implementing communities had the RFFP not taken place. Our interview findings also show ways in which the conditionality of formal RFFP policy was not realized in practice, as poor survival rates did not cause payments to be withheld. In contrast to authors who claim that such patterns show that policymakers should intensify conditionality and more precisely match compensation to marginal costs (Chen et al., 2009; Komarek et al., 2014), we raise these points with recognition of the trade-offs involved in efforts to shape livelihoods and landscapes through policy intervention (Hirsch et al., 2011; Lazos-Chavero et al., 2016). With regard to additionality, on the basis of trajectories up to that time, it would have been difficult for officials to anticipate the broader changes that would take place between 2000 and 2014. With regard to conditionality, our qualitative findings echo other studies that highlight the importance of legitimacy in local implementation decisions (Flower, 2009; Gong et al., 2010; He and Sikor, 2015). These observations highlight how in PES programs instrumental aims of achieving environmental service provision must be seen in the context of ethical and political challenges that shape what kinds of interventions are workable (Muradian et al., 2010).

\subsection{Qualifying forest transitions}

In northwest Yunnan, the narrative of a state-led forest transition pathway may not be adequate to the empirical evidence. The absence of significant RFFP effects and the importance of behavioral indicators suggest that other pathways are at work as outmigration, changing energy sources, and walnut cultivation promote canopy expansion alongside a countervailing trend of cash crop expansion. These relationships have shifted over time from a smallholderintensification pattern to one that more resembles a development pathway. This temporal pattern may confirm the suggestion in Meyfroidt and Lambin (2008) that smallholder intensification processes in Vietnam's uplands would give way to development-led dynamics.
Nonetheless, the recent pattern we observed differs from development pathways in two key ways. First, walnut plantations made an appreciable contribution to canopy expansion, particularly at lower elevations. Second, forest growth in at high elevations have slowed as farmers plant new cash crops. Together, these two trends yield a pattern of canopy growth at lower elevations that diverges from the expectation that development pathways bring vegetation recovery on high-elevation, marginal lands. The proliferation of high-elevation crops, particularly medicinal crops such as costus root and maca (Lepidium meyenii), is transforming upslope lands across southwest China. This trend may bring a regional reversal of widespread abandonment of marginal cropland that has been evident since the 1990s.

While high-elevation medicinal crop cultivation may be distinct to the region, walnut cultivation in Yunnan instantiates a broadly recognized spread of fruit, nut, and pulp plantations across China (Frayer et al., 2014b; Zinda et al., 2017) and other countries (Rudel, 2009; Rudel et al., 2016). This expansion of tree plantations differs from expectations under either a smallholder intensification pathway or a development pathway in its spatial distribution and in its policy and market drivers. Plantations are expanding rapidly in areas of middling agricultural productivity rather than the most marginal areas. Moreover, walnut cultivation is not driven entirely by private incentives but by aggressive policies that instrumentalize market mechanisms. In line with state initiatives promoting oil-bearing tree crops, local forestry agencies have urged residents to plant walnut trees, providing seedlings and extension training.

This phenomenon might be called a "policy plantation" pathway of tree cover transition. Frayer et al. (2014a, 2014b) identify a similar pattern in a nearby region with the smallholder intensification pathway. We argue that the association with off-farm work, contrasting spatial distribution, and hybrid state-market character constitute a distinct configuration. The policy plantation pathway shares with the state-led pathway propulsion by state policy. However, the policies in question trade obligatory planting for incentive mechanisms, and they emphasize not regenerating natural forest but promoting commodity production. It shares with the smallholder intensification pathway a pattern of smallholders planting trees and concentrating staple production. But in contrast with the smallholder intensification pathway, it exhibits a flow of labor off of farms facilitated by infrastructure expansion. Tree plantation concentrates in areas of middling productivity, creating a patchwork landscape of orchards that are monocrops or mixtures of a handful of cultivars. As states promote tree crops through policy inducements or by facilitating corporate land acquisition, particularly in 
China and southeast Asia, such a pattern may become increasingly common.

\subsection{Constraints}

The choices involved in linking social and environmental data across scales and time frames brought several constraints. Our regionally confined sample of communities prevents us from making deterministic claims about how the RFFP and related processes play out in other locales. Due to limited availability of cloud-free images, our land change data reflect periods of differing lengths, potentially obscuring trends that vary across temporal scales (Van Den Hoek et al., 2014). The use of base images of varying resolutions may impact land cover measures across time periods, though the generalization procedure minimizes this effect, and we found no evidence of systematic bias in the directions that would be expected if resampling brought systematic error. A more complete study would have employed direct measures of forest use during each time period examined. Our survey and focus group interviews included several forms of forest use, including home construction, firewood gathering, and non-timber forest product harvest, but imprecision and recall bias limited the utility of these measures. An adequate direct measurement would require multiple household diaries or direct measurements over long periods, which we were unable to do. Finally, we focus on community-level patterns. Important insights can also be gained from examining household-level determinants of land use. However, extrapolating from household data to broader patterns is hazardous because household choices are clustered due to collective processes (Frayer et al., 2014b). We hope that this study's insights will contribute to efforts to clarify these cross-scale relationships.

\section{Conclusion}

The impacts of afforestation policies must be evaluated together with other processes that impact vegetation. Forest transition pathway categories are useful orienting tools that draw broad patterns into focus. But as with any conceptual tool, if we cling too tightly to this instrument, its categorical lenses may distort our focus. In particular, the state-led pathway highlights how national policies influence land cover change. But when policy implementation coincides with other social and economic changes that affect land use, careful investigation is necessary to ascertain which processes predominate (Clement and Amezaga, 2008; Lambin and Meyfroidt, 2010). Such work offers the prospects of both refining forest transition theory and providing empirical evidence that may facilitate policy refinement and targeting.

Incentive-based programs continue to be an important tool for land management in China and elsewhere. The affirmation of REDD+ at the 2015 United Nations Climate Change Conference makes it likely that such programs will continue to proliferate worldwide. Within China, government agencies recently announced a "second round" of RFFP implementation, this time linking conditional payments to satellite-based monitoring (State Forestry Administration, 2013). While these actions may make the program more consistent with formal PES frameworks, there is a risk that without adequate consideration of social and economic contexts, program implementation will hit obstacles or stoke conflicts. Moreover, initial evidence indicates that the new RFFP will intensify reliance on commercial tree crops, suggesting that the program will consolidate the policy plantation pathway in China, particularly in upland areas.

As tree plantations grow in importance in land cover and commodity production, we have a great deal of work to do to understand their multivalent impacts. Plantation forests can pro- vide habitat and other services, depending on management and environmental context (Brockerhoff et al., 2008). But intensely managed monocrop plantations may be inferior to other afforestation approaches on a variety of measures (Fox et al., 2014). Social impacts are even less well studied. One area of relative clarity is that the breadth of benefits of plantations will depend on smallholders' security of tenure and access (Rudel et al., 2016). Livelihood options and policy measures that confer resilience to market volatility will also matter.

The success of the next round of RFFP will likely depend on the extent to which implementation takes into account parallel and countervailing processes that shape how people undertake and maintain tree plantation. This concern harkens to a desideratum of Chinese policy discourse, yindizhiyi: implement in accordance with local conditions. Our evidence suggests that people on the ground have long recognized this point, struggling to access program benefits, integrate tree planting into livelihood strategies, and contain costs the program can bring. Locally adapted and responsive implementation will be vital to ensuring that the next generation of forest policies serves citizens and countrysides well.

\section{Acknowledgments}

We are grateful for the kindness and generosity of the people in Yunnan who allowed us into their communities and helped us conduct our work. Yang Jida, Li Jin, Li Shuangliang, Zhang Zhengkai, Chen Yingyun, Wang Xinfu, Fangyue Genwang, Xiao Guoya, Zhu Yunhao, and Wang Bin did invaluable and demanding work collecting and preparing data. We also thank Leah VanWey, Jamon Van Den Hoek, Lucas Gutiérrez Rodríguez, and anonymous reviewers for incisive comments that helped us refine our thinking. This research was conducted with support from the National Science Foundation, award number SMA-1415028, and from the National Natural Science Foundation of China, award number 41361046. Fieldwork and initial analysis were conducted while the second author was located at the Institute at Brown for Environment and Society, Brown University.

\section{References}

Agrawal, A., Wollenberg, E., Persha, L., 2014. Governing agriculture-forest landscapes to achieve climate change mitigation. Glob. Environ. Change 29 270-280, http://dx.doi.org/10.1016/j.gloenvcha.2014.10.001.

Alix-Garcia, J., Wolff, H., 2014. Payment for ecosystem services from forests. Annu. Rev. Resour. Econ. 6, 361-380, http://dx.doi.org/10.1146/annurev-resource100913-012524.

Atkinson, P.M., Tatnall, A.R.L., 1997. Introduction Neural networks in remote sensing. Int. J. Remote Sens. 18, 699-709, http://dx.doi.org/10.1080/ 014311697218700

Benediktsson, J.A., Swain, P.H., Ersoy, O.K., 1990. Neural network approaches versus statistical methods In classification of multisource remote sensing data. IEEE Trans. Geosci. Remote Sens. 28, 540-552, http://dx.doi.org/10.1109/TGRS. $; 1 ; 1990.572944$

Bennett, M.T., Xie, C., Hogarth, N.J., Peng, D., Putzel, L., 2014. China's conversion of cropland to forest program for household delivery of ecosystem services: how important is a local implementation regime to survival rate outcomes? Forests 5, 2345-2376, http://dx.doi.org/10.3390/f5092345.

Bennett, M.T., 2008. China's sloping land conversion program: institutional innovation or business as usual? Ecol. Econ. 65, 699-711, http://dx.doi.org/10. 1016/j.ecolecon.2007.09.017.

Brockerhoff, E.G., Jactel, H., Parrotta, J.A., Quine, C.P., Sayer, J., 2008. Plantation forests and biodiversity: oxymoron or opportunity? Biodivers. Conserv. 17, 925-951, http://dx.doi.org/10.1007/s10531-008-9380-x.

Bullock, A., King, B., 2011. Evaluating China's slope land conversion program as sustainable management in tianquan and wuqi counties. J. Environ. Manage. 92, 1916-1922, http://dx.doi.org/10.1016/j.jenvman.2011.03.002. 
Chazdon, R.L., 2008. Beyond deforestation: restoring forests and ecosystem services on degraded lands. Science 320, 1458-1460, http://dx.doi.org/10. $1126 /$ science. 1155365.

Chen, X., Lupi, F., He, G., Ouyang, Z., Liu, J., 2009. Factors affecting land reconversion plans following a payment for ecosystem service program. Biol. Conserv. 142, 1740-1747, http://dx.doi.org/10.1016/j.biocon.2009.03.012.

Chen, H., Marter-Kenyon, J., López-Carr, D., Liang, X., 2015. Land cover and landscape changes in shaanxi province during China's grain for green program (2000-2010). Environ. Monit. Assess. 187, 1-14, http://dx.doi.org/10.1007/ s10661-015-4881-z.

Clement, F., Amezaga, J.M., 2008. Linking reforestation policies with land use change in northern Vietnam: why local factors matter. Geoforum 39, 265-277, http://dx.doi.org/10.1016/j.geoforum.2007.05.008.

Conservation International, 2015. Mountains of Southwest China [WWW Document]. Crit. Ecosyst. Partnersh. Fund, URL http://www.cepf.net/resources/ hotspots/Asia-Pacific/Pages/Mountains-of-Southwest-China.aspx. (Accessed 27 October 15).

Corbera, E., Brown, K., Adger, W.N., 2007. The equity and legitimacy of markets for ecosystem services. Dev. Change 38, 587-613, http://dx.doi.org/10.1111/j. 1467-7660.2007.00425.x.

Daniels, A.E., Bagstad, K., Esposito, V., Moulaert, A., Rodriguez, C.M., 2010. Understanding the impacts of Costa Rica's PES: Are we asking the right questions? Ecol. Econ. 69, 2116-2126, http://dx.doi.org/10.1016/j.ecolecon. 2010.06.011.

Deng, L., Shangguan, Z., Li, R., 2012. Effects of the grain-for-green program on soil erosion in China. Int. J. Sediment Res. 27, 120-127, http://dx.doi.org/10.1016/ S1001-6279(12)60021-3.

Engel, S., Pagiola, S., Wunder, S., 2008. Designing payments for environmenta services in theory and practice: an overview of the issues. Ecol. Econ. 65, 663-674, http://dx.doi.org/10.1016/j.ecolecon.2008.03.011.

Flower, J., 2009. Ecological engineering on the Sichuan frontier: socialism as development policy, local practice, and contested ideology. Soc. Anthropol. 17, 40-55, http://dx.doi.org/10.1111/j.1469-8676.2008.00056.x.

Fox, J., Castella, J.-C., Ziegler, A.D., 2014. Swidden, rubber and carbon: can REDD+ work for people and the environment in Montane Mainland Southeast Asia? Glob. Environ. Change 29, 318-326, http://dx.doi.org/10.1016/j.gloenvcha. 2013.05.011.

Frayer, J., Müller, D., Sun, Z., Munroe, D.K., Xu, J., 2014a. Processes underlying 50 years of local forest-cover change in Yunnan, China. Forests 5, 3257-3273, http://dx.doi.org/10.3390/f5123257.

Frayer, J., Sun, Z., Müller, D., Munroe, D.K., Xu, J., 2014b. Analyzing the drivers of tree planting in Yunnan China, with Bayesian networks. Land Use Policy 36, 248-258, http://dx.doi.org/10.1016/j.landusepol.2013.08.005.

Gong, Y., Bull, G., Baylis, K., 2010. Participation in the world's first clean development mechanism forest project: the role of property rights, social capital and contractual rules. Ecol. Econ. 69, 1292-1302, http://dx.doi.org/10. 1016/j.ecolecon.2009.11.017.

Gutiérrez Rodríguez, L., Hogarth, N.J., Zhou, W., Xie, C., Zhang, K., Putzel, L., 2016. China's conversion of cropland to forest program: a systematic review of the environmental and socioeconomic effects. Environ. Evid. 5, 21, http://dx.doi. org/10.1186/s13750-016-0071-x.

He, J., Lang, R., 2015. Limits of state-led programs of payment for ecosystem services: field evidence from the sloping land conversion program in southwest China. Hum. Ecol. 43, 749-758, http://dx.doi.org/10.1007/s10745015-9782-9.

He, J., Sikor, T., 2015. Notions of justice in payments for ecosystem services: insights from China's sloping land conversion program in yunnan province. Land Use Policy 43, 207-216, http://dx.doi.org/10.1016/j.landusepol.2014.11. 011.

He, J., Lang, R., Xu, J., 2014. Local dynamics driving forest transition: insights from Upland villages in southwest China. Forests 5, 214-233, http://dx.doi.org/10. 3390/f5020214.

Hecht, S., 2010. The new rurality: globalization, peasants and the paradoxes of landscapes. Land Use Policy, Forest transitions Wind power planning, landscapes and publics 27, 161-169, http://dx.doi.org/10.1016/j.landusepol. 2009.08.010.

Hirsch, P.D., Adams, W.M., Brosius, J.P., Zia, A., Bariola, N., Dammert, J.L., 2011 Acknowledging conservation trade-Offs and embracing complexity. Conserv. Biol. 25, 259-264, http://dx.doi.org/10.1111/j.1523-1739.2010.01608.x.

Jenness, J., 2006. Topographic Position Index (tpi_jen.avx) extension for ArcView 3 $\mathrm{X}, \mathrm{v}$. 1.3a. Jenness Enterprises.

Kelly, P., Huo, X., 2013. Land retirement and nonfarm labor market participation: an analysis of China's sloping land conversion program. World Dev. 48 , 156-169, http://dx.doi.org/10.1016/j.worlddev.2013.04.002.

Klooster, D., 2003. Forest transitions in Mexico: institutions and forests in a globalized countryside. Prof. Geogr. 55, 227-237, http://dx.doi.org/10.1111/ 0033-0124.5502010.

Komarek, A.M., Shi, X., Heerink, N., 2014. Household-level effects of China's sloping land conversion program under price and policy shifts. land use policy. Land Use Policy in China 40, 36-44, http://dx.doi.org/10.1016/j.landusepol.2013.04 013.

Kosoy, N., Corbera, E., Brown, K., 2008. Participation in payments for ecosystem services: case studies from the Lacandon rainforest, Mexico. Geoforum 39, 2073-2083, http://dx.doi.org/10.1016/j.geoforum.2008.08.007.

Lü, Y., Fu, B., Feng, X., Zeng, Y., Liu, Y., Chang, R., Sun, G., Wu, B., 2012. A policy-Driven large scale ecological restoration: quantifying ecosystem services changes in the loess plateau of China. PLoS One 7, e31782, http://dx doi.org/10.1371/journal.pone.0031782.

Lambin, E.F., Meyfroidt, P., 2010. Land use transitions: socio-ecological feedback versus socio-economic change. Land Use Policy, Forest transitions Wind power planning, landscapes and publics 27, 108-118, http://dx.doi.org/10.1016/j. landusepol.2009.09.003.

Lambin, E.F., Meyfroidt, P., 2011. Global land use change, economic globalization, and the looming land scarcity. Proc. Natl. Acad. Sci. 108, 3465-3472, http://dx. doi.org/10.1073/pnas.1100480108.

Lambin, E.F., Meyfroidt, P., Rueda, X., Blackman, A., Börner, J., Cerutti, P.O., Dietsch, T., Jungmann, L., Lamarque, P., Lister, J., Walker, N.F., Wunder, S., 2014. Effectiveness and synergies of policy instruments for land use governance in tropical regions. Glob. Environ. Change 28, 129-140, http://dx.doi.org/10.1016 j.gloenvcha.2014.06.007.

Lazos-Chavero, E., Zinda, J., Bennett-Curry, A., Balvanera, P., Bloomfield, G., Lindell, C., Negra, C., 2016. Stakeholders and tropical reforestation: challenges, trade-offs, and strategies in dynamic environments. Biotropica 48, 900-914, http://dx.doi.org/10.1111/btp.12391.

Li, Y., Viña, A., Yang, W., Chen, X., Zhang, J., Ouyang, Z., Liang, Z., Liu, J., 2013. Effects of conservation policies on forest cover change in giant panda habitat regions, China. Land Use Policy 33, 42-53, http://dx.doi.org/10.1016/j.landusepol.2012. 12.003.

Liang, Y., Li, S., Feldman, M.W., Daily, G.C., 2012. Does household composition matter? The impact of the Grain for Green Program on rural livelihoods in China. Ecol. Econ. 75, 152-160, http://dx.doi.org/10.1016/j.ecolecon.2012.01. 019.

Lin, Y., Yao, S., 2014. Impact of the sloping land conversion program on rural household income: an integrated estimation. land use policy. Land Use Policy in China 40, 56-63, http://dx.doi.org/10.1016/j.landusepol.2013.09.005.

Liu, Z., Lan, J., 2015. The sloping land conversion program in China: effect on the livelihood diversification of rural households. World Dev. 70, 147-161, http:// dx.doi.org/10.1016/j.worlddev.2015.01.004.

Liu, J., Li, S., Ouyang, Z., Tam, C., Chen, X., 2008. Ecological and socioeconomic effects of China's policies for ecosystem services. Proc. Natl. Acad. Sci. 105, 9477-9482, http://dx.doi.org/10.1073/pnas.0706436105.

Liu, T., Liu, C., Liu, H., Wang, S., Rong, Q., Zhu, W., 2014. Did the key priority forestry programs affect income inequality in rural China? Land Use Policy 38, 264-275, http://dx.doi.org/10.1016/j.landusepol.2013.11.016.

Mas, J.F., Flores, J.J., 2008. The application of artificial neural networks to the analysis of remotely sensed data. Int. J. Remote Sens. 29, 617-663, http://dx. doi.org/10.1080/01431160701352154.

Mather, A.S., Needle, C.L., 1998. The forest transition: a theoretical basis. Area 30, 117-124, http://dx.doi.org/10.1111/j.1475-4762.1998.tb00055.x.

Mather, A.S., 1992. The forest transition. Area 24, 367-379.

Mather, A.S., 2007. Recent asian forest transitions in relation to forest-Transition theory. Int. For. Rev. 9, 491-502, http://dx.doi.org/10.1505/ifor.9.1.491.

Meyfroidt, P., Lambin, E.F., 2008. The causes of the reforestation in Vietnam. Land Use Policy 25, 182-197, http://dx.doi.org/10.1016/j.landusepol.2007.06.001.

Meyfroidt, P., Lambin, E.F., 2011. Global forest transition: prospects for an end to deforestation. Annu. Rev. Environ. Resour. 36, 343-371, http://dx.doi.org/10. 1146/annurev-environ-090710-143732.

Miles, M.B., Huberman, A.M., 1994. Sampling: Bounding the Collection of Data, In: Qualitative Data Analysis: An Expanded Sourcebook. Sage, Thousand Oaks, pp. 27-34.

Muradian, R., Corbera, E., Pascual, U., Kosoy, N., May, P.H., 2010. Reconciling theory and practice: an alternative conceptual framework for understanding payments for environmental services. Ecol. Econ. 69, 1202-1208, http://dx.doi. org/10.1016/j.ecolecon.2009.11.006.

Perz, S.G., Skole, D.L., 2003. Secondary forest expansion in the Brazilian Amazon and the refinement of forest transition theory. Soc. Nat. Resour. 16, 277-294, http://dx.doi.org/10.1080/08941920390178856.

Perz, S.G., 2007. Grand theory and context-specificity in the study of forest dynamics: forest transition theory and other directions. Prof. Geogr. 59, 105-114, http://dx.doi.org/10.1111/j.1467-9272.2007.00594.x.

Petit, C.C., Lambin, E.F., 2001. Integration of multi-source remote sensing data for land cover change detection. Int. J. Geogr. Inf. Sci. 15, 785-803, http://dx.doi. org $/ 10.1080 / 13658810110074483$.

Qin, H., 2010. Rural-to-urban labor migration, household livelihoods, and the rural environment in chongqing municipality, southwest China. Hum. Ecol. 38, 675-690, http://dx.doi.org/10.1007/s10745-010-9353-z.

Robbins, A.S.T., Harrell, S., 2014. Paradoxes and challenges for China's forests in the reform era. China Q., 381-403, http://dx.doi.org/10.1017/S0305741014000344.

Rudel, T.K., Bates, D., Machinguiashi, R., 2002. A tropical forest transition? agricultural change, out-migration, and secondary forests in the ecuadorian amazon. Ann. Assoc. Am. Geogr. 92, 87-102, http://dx.doi.org/10.1111/14678306.00281.

Rudel, T.K., Coomes, O.T., Moran, E., Achard, F., Angelsen, A., Xu, J., Lambin, E., 2005 Forest transitions: towards a global understanding of land use change. Glob. Environ. Change 15, 23-31, http://dx.doi.org/10.1016/j.gloenvcha.2004.11.001.

Rudel, T.K., Sloan, S., Chazdon, R., Grau, R., 2016. The drivers of tree cover expansion: global, temperate, and tropical zone analyses. Land Use Policy 58 502-513, http://dx.doi.org/10.1016/j.landusepol.2016.08.024.

Rudel, T.K., 2009. Tree farms: driving forces and regional patterns in the global expansion of forest plantations. Land Use Policy 26, 545-550, http://dx.doi.org/ 10.1016/j.landusepol.2008.08.003. 
SFA Economic Development Research Center and SFA Department of Development Planning and Assets Management, 2006. A Report for Monitoring and Assessment of the Socio-economic Impacts of China's Key Forestry Programs 2005. China Forestry Publishing Company, Beijing (in Chinese)

Song, C., Zhang, Y., Mei, Y., Liu, H., Zhang, Z., Zhang, Q., Zha, T., Zhang, K., Huang, C. Xu, X., Jagger, P., Chen, X., Bilsborrow, R., 2014. Sustainability of forests created by China's sloping land conversion program: a comparison among three sites in Anhui, Hubei and Shanxi. For. Policy Econ. 38, 161-167, http://dx.doi.org/10. 1016/j.forpol.2013.08.012.

State Council of the People's Republic of China, 2002. Articles for Returning Farmland to Forest (in Chinese).

State Forestry Administration, 2013. Returning Farmland to Forest: Anticipating a Renewed L = launch (Accessed 9 July 2014 at http://tghl.forestry.gov.cn/portal/ $\operatorname{tghl} / \mathrm{s} / 3815 /$ content-617743.html. [in Chinese]).

State Forestry Administration, 2014. 20132013 National Monitoring Report on the Ecological Effectiveness of the Returning Farmland to Forest Program. China Forestry Publishing Company, Beijing [in Chinese].

Trac, C., Harrell, S., Hinckley, T., Henck, A., 2007. Reforestation programs in Southwest China: reported success, observed failure, and the reasons why. J. Mt. Sci. 4, 275-292, http://dx.doi.org/10.1007/s11629-007-0275-1.

Trac, C.J., Schmidt, A.H., Harrell, S., Hinckley, T.M., 2013. Is the Returning Farmland to Forest Program a success? three case studies from Sichuan. Environ. Pract. 15, 350-366, http://dx.doi.org/10.1017/S1466046613000355.

Uchida, E., Xu, J., Xu, Z., Rozelle, S., 2007. Are the poor benefiting from China's land conservation program? Environ. Dev. Econ. 12

Uchida, E., Rozelle, S., Xu, J., 2009. Conservation payments liquidity constraints, and off-farm labor: impact of the grain-for-green program on rural households in China. Am. J. Agric. Econ. 91, 70-86, http://dx.doi.org/10.1111/j.1467-8276. 2008.01184.x.

Van Den Hoek, J., Ozdogan, M., Burnicki, A., Zhu, A.-X., 2014. Evaluating forest policy implementation effectiveness with a cross-scale remote sensing analysis in a priority conservation area of Southwest China. Appl. Geogr. 47, 177-189, http://dx.doi.org/10.1016/j.apgeog.2013.12.010.

Wang, Dong-hua, 2006. Research and implementation of construction of 1:50 000 scale topographic database in China. Geomat. World, 4-5 (in Chinese)

Willson, A., 2006. Forest conversion and land use change in rural northwest yunnan. China. Mt. Res. Dev. 26, 227-236.

Wunder, S., 2005. Payments for Environmental Services: Some Nuts and Bolts, CIFOR Occasional Paper No. 42. Center for International Forestry Research, Jakarta, Indonesia.

Wunder, S., 2008. Payments for environmental services and the poor: concepts and preliminary evidence. Environ. Dev. Econ. 13, 279-297, http://dx.doi.org/10. 1017/S1355770x08004282.
Wunder, S., 2015. Revisiting the concept of payments for environmental services Ecol. Econ. 117, 234-243, http://dx.doi.org/10.1016/j.ecolecon.2014.08.016.

Xu, J., Cao, Y., 2002. The socioeconomic impacts and sustainability of the SLCP. In: Xu, J., Katsigris, E., White, T.A. (Eds.), Implementing the Natural Forest Protection Program and the Sloping Land Conversion Program: Lessons and Policy Recommendations. China Council for International Cooperation on Environment and Development, Beijing, pp. 52-61.

Xu, J., Wilkes, A., 2004. Biodiversity impact analysis in northwest Yunnan, southwest China. Biodivers. Conserv. 13, 959-983, http://dx.doi.org/10.1023/ B:BIOC.; 1;0000014464.80847.02.

Xu, J., Yang, Y., Fox, J., Yang, X., 2007. Forest transition, its causes and environmental consequences: empirical evidence from Yunnan of Southwest China. Trop. Ecol. 48, 137-150.

Xu, J., Tao, R., Xu, Z., Bennett, M.T., 2010. China's sloping land conversion program: does expansion equal success? Land Econ. 86, 219-244.

Yang Hongcheng, 2013. Weixi County Implements Ecological County Strategy. Yunnan Net (Accessed 17 September 2013 at http://diqing.yunnan.cn/html/ 2013-08/23/content_2856929.htm. [in Chinese]).

Yao, S., Guo, Y., Huo, X., 2010. An empirical analysis of the effects of China's land conversion program on farmers' income growth and labor transfer. Environ. Manage. 45, 502-512, http://dx.doi.org/10.1007/s00267-009-9376-7.

Yin, R., Liu, C., Zhao, M., Yao, S., Liu, H., 2014. The implementation and impacts of China's largest payment for ecosystem services program as revealed by longitudinal household data. Land Use Policy. Land Use Policy in China 40, 45-55, http://dx.doi.org/10.1016/j.landusepol.2014.03.002.

Zhai, D.-L., Xu, J.-C., Dai, Z.-C., Cannon, C.H., Grumbine, R.E., 2013. Increasing tree cover while losing diverse natural forests in tropical Hainan, China. Reg. Environ. Change, 1-11, http://dx.doi.org/10.1007/s10113-013-0512-9.

Zhang, Z., van Coillie, F., Ou, X., de Wulf, R., 2014. Integration of satellite imagery, topography and human disturbance factors based on canonical correspondence analysis ordination for mountain vegetation mapping: a case study in Yunnan, China. Remote Sens. 6, 1026-1056, http://dx.doi.org/10.3390/rs6021026.

Zhen, N., Fu, B., Lü, Y., Zheng, Z., 2014. Changes of livelihood due to land use shifts: a case study of Yanchang County in the Loess Plateau of China. Land Use Policy. Land Use Policy in China 40, 28-35, http://dx.doi.org/10.1016/j.landusepol. 2013.05.004.

Zhou, S., Yin, Y., Xu, W., Ji, Z., Caldwell, I., Ren, J., 2007. The costs and benefits of reforestation in liping county, guizhou province, China. J. Environ. Manage. 85, 722-735, http://dx.doi.org/10.1016/j.jenvman.2006.08.014.

Zinda, J.A., Trac, C.J., Zhai, D., Harrell, S., 2017. Dual-function forests in the Returning Farmland to Forest Program and the flexibility of environmental policy in China. Geoforum 78, 119-132, http://dx.doi.org/10.1016/j.geoforum. 2016.03.012. 